\title{
Al-Qur'an dan Budaya: Al-Qur'an dalam Siklus Kehidupan Muslim
}

\author{
Ali Ridho \\ Universitas Islam Negeri (UIN) Sunan Kalijaga Yogyakarta \\ Jl. Laksda Adisucipto, Papringan, Caturtunggal, Kec. Depok, \\ Kabupaten Sleman, Daerah Istimewa Yogyakarta 55281 \\ E-mail: ridhoali975@gmail.com
}

\begin{abstract}
Abstrak
Tujuan tulisan ini adalah untuk mengetahui hubungan antara Al-Qur'an dan Budaya serta bagaimana menjadi seorang Muslim yang baik dengan dilandasi nilai-nilai Al-Qur'an dan Budaya. Metode penelitian yang digunakan adalah kualitatif dalam bentuk studi kepustakaan. Data dikumpulkan dengan cara riset buku dan jurnal serta sumber lainnya yang mendukung kegiatan penelitian. Hasil dari penelitian ini adalah Islam bukanlah lahir dari produk budaya. Akan tetapi, justru membangun sebuah budaya, sebuah peradaban. Peradaban berdasarkan Al-Qur'an dan Sunnah Nabi Saw. tersebut yang pada akhirnya dinamakan dengan perdaban Islam. Dengan kita dapat memulai untuk meletakkan Islam dalam kehidupan keseharaian. Membangun kebudayaan Islam dengan landasan konsep yang berasal dari Islam dengan sumbernya adalah Al-Qur'an. Kehidupan seorang Muslim haruslah sesuai dengan aturan-aturan yang ditetapkan Al-Qur'an. Muslim harus mampu dan enggan (keinginan) menjunjung tinggi budaya yang menjadi identitas lokal pada dirinya dengan pondasi nilai-nilai suci yang ada dalam Al-Qur'an. Diantaranya adalah sikap ikhlas, ber-ilmu dan jujur menjadi pribadi Muslim dalam menjalani pergulatan waktu yang terus berubah seiring dengan berubahnya pola peradaban manusia. Sehingga, tidak ada alasan bagi seorang Muslim untuk menghilangkan identitas budayanya demi menjadi seorang Muslim yang baik. Sebab, Al-Qur'an dan Budaya adalah pakaian yang cocok untuk dikenakan oleh setiap orang Muslim dalam setiap penggalan ritus kehidupan.
\end{abstract}

Kata Kunci: Al-Qur’an, Budaya, Kehidupan, Muslim

\section{Abstrack}

The purpose of this paper is to find out the relationship between the Qur'an and Culture and how to become a good Muslim based on the values of the Qur'an and Culture. The research method used is qualitative in the form of library studies. Data is collected by researching books and journals and other sources that support research activities. The results of this study are that Islam is not born of cultural products. However, it builds a culture, a civilization. A civilization based on the Qur'an and the Sunnah of the Prophet. that is finally called Islamic civilization. With this, we can begin to put Islam in our daily lives. Building Islamic culture with a foundation of concepts derived from Islam with its source is the Qur'an. The life of a Muslim must be following the rules set by the Qur'an. Muslims must be able and reluctant (upholding) to uphold a culture that is a local identity in themselves with the foundation of the holy values contained in the Qur'an. 
Among them is a sincere, knowledgeable and honest attitude to be a Muslim person in undergoing a time struggle that continues to change along with changing patterns of human civilization. Thus, there is no reason for a Muslim to lose his cultural identity to become a good Muslim. Because AlQur'an and Culture are clothes that are suitable to be worn by every Muslim in every fragment of life rites.

\section{Keywords: Al-Qur'an, Culture, Life, Muslims}

\section{A. PENDAHULUAN}

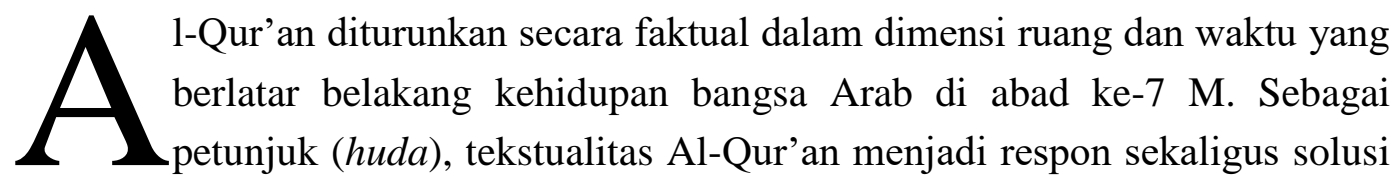
bagi konpleksitas tradisi dan permasalahan masyarakat Arab di zaman itu yang masih relatif sederhana dalam pola pikir dan teknologi.

Adapun secara kontekstual, Al-Qur'an jelas ditujukan bagi segenap disparitas ruang dan waktu umat manusia, terlepas dari apapun kondisi geografis dan sosiologiskultural yang mengitarinya. Keterikatan Al-Qur'an dengan aspek sosio-kultural dalam sejarah kehidupan kehidupan manusia merupakan fenomena yang sangat unik. Sebagai sebuah wahyu, pada hakikatnya sudah pasti Al-Qur'an menjadi sakral dan transdental, tidak terjamah oleh segala bentuk pengaruh kesejarahan. Namun secara faktual dibuktikan dalam sejarah betapa Al-Qur'an selama proses pewahyuannya telah melakukan dialog dan dialektika dengan kebudayaan manusia. Kita mengenal konsep naskh, makki-maddani, asbab al-nuzul, dan sebagainya yang mengartikulasikan wujud dialektika itu. Di samping menolak dan memberi alternatif, Al-Qur'an juga telah menunjukkan dinamisasinya dalam menyerap, menginternalisasi, dan merekonstruksi begitu banyak konsep-konsep kebudayaan yang dikenal kala itu.

Kemudian tak bisa dipungkiri, manusia merupakan makhluk berbudaya. Dengan daya cipta, rasa, dan karsa, manusia memproduksi kebudayaananya. (Koentjaraningrat, 1990, p. 193, 2004, pp. 5-6) Ia lahir dan hidup dalam pluralitas ruang budaya yang diproduksinya agar saling kenal-mengenal, saling menghargai eksistensi masing-masing (QS. Al-Hujurat (49): 13). Dengan demikian, pluralitas budaya, baik berupa eksistensi kelompok-kelompok berbeda secara etnis, ras, bahasa, bahkan agama harus disadari dan diterima. Karena penerimaan akan pluralitas budaya ini, kaum Muslimin meski menganggap kesatuan umat Islam (Ummah Wahidah) sebagai identitas bersama umumnya memegang erat identitas lainnya seperti kesukuan atau etnis. (Rohmana, 2014, p. 80)

Interkonektivitas antara Al-Qur'an dan Budaya haruslah mewarnai kehidupan seorang muslim. Apabila Al-Qur'an yang notabene berasal dari Tuhan (baca: Allah) dan budaya merupakan produk manusia dengan beragam pernak-perniknya, ternyata 
ditemukan memiliki kecocokan dalam membangun peradaban Islam dan Kaum Muslim. Maka tulisan ini akan membahas mengenai Al-Qur'an dan Budaya: Al-Qur'an dalam Siklus Kehidupan Muslim.

\section{B. AL-QURAN DAN SPIRIT PEMBENTUK BUDAYA}

Al-Qur'an merupakan kitab suci umat Islam, sekalipun tidak memberikan petunjuk langsung tentang suatu bentuk dinamika masyarakat, namun tetap memberikan petunjuk mengenai ciri-ciri dan kualitas sebuah kebudayaan masyarakat, walaupun semua itu memerlukan upaya interpretasi dan pengembangan pemikiran yang kompleksitas. Di samping itu, Al-Qur'an juga memerintahkan kepada Umat manusia untuk memikirkan pembentukan dan dinamika suatu peradaban dengan kualitas-kualitas tertentu, dan sangat mungkin bagi umat Islam untuk merekonstruksikan suatu kebudayaan yang ideal berdasarkan petunjuk Al-Qur'an.

Al-Qur'an sebagai sebuah kitab yang meletakkan amal sebagai sentral bagi makna keberadaan manusia. (Madjid, 1992, p. 61) Pandangan ini menempatkan manusia pada posisi yang dinamis, dinamikanya terletak pada eksistensi manusia yang terus-menerus berada dalam proses, yaitu proses pernyataan keberadaan, baik yang bersifat individu maupun yang kolektif. Ini artinya manusia dalam menjalani proses kehidupannya di dunia tidak boleh bersikap pasif dan pasrah, tetapi justru harus diwujudkan dalam sikap aktif, memanfaatkan lingkungannya untuk kepentingan hidup dan kehidupannya, dan dari sikap aktif itulah kemudian muncul kebudayaan. (Muhaimin, 2005, p. 333)

Terkait dengan kebudayaan, maka ia memiliki ruang lingkup yang sangat luas, mencakup segala aspek kehidupan manusia, baik ruhaniah maupun jasmaniah. Bertolak dari manusia, khususnya jiwa, terkhusus lagi pikir dan rasa, Sidi Gazalba merumuskan kebudayaan adalah "cara berpikir dan merasa, menyatakan diri dalam seluruh segi kehidupan sekelompok manusia yang membentuk masyarakat, dalam suatu ruang dan waktu. (Gazalba, 1989, p. 12)

\section{AL-QUR'AN DAN SPIRIT DIAEKTIKA BUDAYA}

Sejarah klasik tinjauan sejarah menunjukkan bahwa pada mulanya Al-Qur'an adalah sebuah konsep sederhana yang juga dipahami secara sederhana yang juga dipahami secara sederhana oleh kaum muslim. Ia adalah kalam (firman) yang baik bahasa dan bentuknya maupun kandungan maknanya secara murni dan simultan diturunkan dari hadirat Allah Swt. kepada Nabi Muhammad Saw. (Al-Faruqi, 1998, p. 138) 
Pada akhir abad ke-2 H/8 M, konsep Al-Qur'an mulai dipersoalkan oleh kelompok Mu'tazilah dengan doktrin terkenalnya: "Al-Qur'an diciptakan (makhluk)", logikanya cukup sederhana, yaitu apabila Al-Qur'an tidak makhluk berarti ia merupakan Tuhan itu sendiri, sedangkan zat Tuhan mustahil dibagi-bagi atau terdiri dari komponen-komponen. Sungguh doktrin ini pun akhirnya menghasilkan kecaman serius dari arus utama umat Islam, namun posisi politik Mu'tazilah yang sedang di atas angin menjadikan mereka lebih berpeluang untuk melakukan indoktrinisasi secara lebih leluasa. Tantangan yang dipelopori oleh kelompok Hanabilah tidak membuat Mu'tazilah surut dengan doktrin ini, bahkan melalui dukungan penguasa politik, mereka melakukan mihnah (inkuisi) agar semua umat Islam mengakui kemakhlukan Al-Qur'an. (Hasyim, 1982, pp. 42-44)

Jika menyimak fenomena Mu'tazilah, tercermin dialektika Al-Qur'an dengan budaya yang kurang proporsional, di mana dalam kasus ini Al-Qur'an direduksi hanya sebatas teks profan yang notabene merupakan prosuk budaya Arab abad ke-7 M. Secara politis, dictum "Al-Qur'an diciptakan" merupakan justifikasi yang sangat kuat bagi upaya-upaya tafsir politik yang melegitimasi setiap kehendak para penguasa, karena dalam posisinya sebagai makhluk, Al-Qur'an tidaklah berbeda dari segala jenis makhluk lain di ala mini yang rentan perubahan dan kebinasaan (fana'). Akan tetapi, Mu'tazilah memiliki alasan tersendiri tentang doktrin ini dengan cara pandang mereka yang khas rasionalis, seperti doktrin ke-Maha Esaan Tuhan. Para ulama belakangan baik langsung maupun tidak berusaha melakukan diferensiasi antara Al-Qur'an sebagai teks dengan statusnya sebagai firman Tuhan. Ulama spesialis ushul al-fiqh misalnya, menetapkan bahwa Al-Qur'an adalah nama bagi keseluruhan Al-Qur' an dan nama bagi setiap suku atau bagian darpadanya. Sementara ulama spesialis ilmu kalam merujuk AlQur'an sebagai kalam azali yang berdir pada zat Tuhan yang senantiasa bergerak (tidak pernah diam) dan tidak pernah ditimpa sesuatu bencana. (Ash-Shiddieqy, 1994, p. 2)

Pada dasarnya, dialektika Al-Qur'an dengan budaya bersifat proporsional, dalam arti teknis bahwa ada bagian-bagian yang saling menyokong atau saling menutupi keterbatasan masing-masing. Al-Qur'an memiliki aspek yang terbuka terhadap fenomena dan gerak realitas budaya manusia, serta selalu mengondisikan diri dengannya, seperti ditunjukkan oleh proses pewahyuannya yang mengambil setting sosial-budaya Arab abad ke-7 M. Dalam bahasa yang spesifik, ayat-ayat Al-Qur'an diturunkan bukan dalam ruang hampa sejarah, melainkan memiliki latar belakang yang menggambarkan turunnya suatu ayat, seperti adanya peristiwa tertentu yang dihadapi Nabi Muhammad Saw. Oleh karenanya ayat-ayat itu seolah-olah ikut memecahkan persoalan kasuistik pada masanya, atau minimal memberikan pedoman dan ketetapan bagaimana hukumnya salah satu persoalan di masa pewahyuan tersebut. 
Di sini pengaruh budaya lokal dalam pewahyuan Al-Qur'an merupakan bentuk interaksi dan dialektika wahyu dengan realitas yang mengada di zaman itu. Dalam ungkapan teologis, karena wahyu ditujukan sebagai pedoman dan solusi kehidupan, secara pasti gerak realitas yang direspon akan turut mewarnai karakter kultural teks ini, jika dilihat secara general, terdiri atas perwujudan teks Al-Qur'an dalam bahasa Arab (qur'anan 'arabiyyan), penurunannya secara bertahap dan berangsur-angsur (tabarruj), serta tergambarnya realitas kebudayaan pada sistem kognisi bangsa Arab di abad ke-7 M. di dalam materi dan struktur teks. Adapun secara spesifik, perwujudan pengaruh tersebut dapat diindra pada terserapnya tradisi budaya yang mengakar kuat dalam kehidupan Arab jahiliyah, gerak krnologis sejarah dari periode Mekkah ke periode Madinah (makki wa madani), serta tahapan kondisi antropologis penerimaan bangsa Arab terhadap Al-Qur'an dan kenabian Muhammad Saw. Semua implikasi pengaruh lokalitas ini dapat disimak dalam teks Al-Qur'an yang sarat makna baik secara material maupun struktural.

\section{PANDANGAN AL-QUR'AN TERHADAP MASYARAKAT DAN KEBUDAYAAN}

Al-Qur'an memandang masyarakat sebagai komunitas sosial dan wahana aktualisasi amal saleh. Banyak ayat Al-Qur'an yang membahas peranan manusia di tengah manusia lain menempatkan nilai-nilai Al-Qur'an sebagai pedoman agama yang paling manusiawi dibandingkan yang lainnya. Hal ini berbanding terbalik dengan pandangan barat yang menempatkan manusia sebagai subjek bebas dari nilai-nilai yang bersumber dari masyarakat. Adapun Al-Qur'an menempatkan manusia sebagai subyek yang tunduk pada nilai-nilai Ilahiyah (Ketuhanan), bukan nilai-nilai yang hanya berkembang di tengah masyarakat. (Syaikhu, 2010, p. 101)

Masyarakat dipandang sebagai wahana pengaktualisasian nilai-nilai Ilahiyah sehingga membentuk kultur agama. Sebaliknya, kultur yang telah berkembang di tengah masyarakat dibina dan kembangkan serta diwarnai ole nilai-nilai Ilahiyah. Al-Qur'an memiliki konsep masyarakat yang menjadi harapannya dan hendak diwujudkan dalam kehidupan umatnya. Konsep masyarakat ideal tersebut dikenal dengan istilah "Masyarakat Marhamah", yaitu masyarakat yang memiliki hubungan erat antara anggota masyarakatnya berdasarkan kasih sayang. (Yusuf, 2002, p. 56)

Jika masuk ke dalam tatatan keagamaan, agama adalah sebuah realitas budaya yang serba relatif yang berubah dan berkembang searah dengan perubahan sosial pemeluk agama itu sendiri. Pada akhirnya, penting dikembangkan model baru paham keagamaan di mana janji surga Tuhan terbuka bagi semua manusia yang benar-benar ikhlas mengabdikan diri pada Tuhan melalui bentuk paling jelas, yaitu pembebasan 
manusia dari segala penderitaan tanpa melihat agama dan banyak "kamar" yang bisa dimasuki dengan beragam jalan atau agama. oleh karena itu, semua manusia berpeluang masuk surga sesuai keagamaan dan kapasitasnya masing-masing jika mereka memang percaya (iman) dan berminat.

Di dalam agama Islam tak mengenal batas geopolitik, budaya asing, atau pribumi dan mengecam keras penolakan budaya hanya karena non-Arab. Belajar hingga ke negeri asing (Cina) justru dianjurkan. Baru sesudah Islam berkembang sebagai identitas politik, budaya Barat Kristen dan non-Arab mulai ditolak yang meluas ke penolakan kebudayaan atau seni. Kebudayaan kemudian ditempatkan sebagai lawan dari agama (Islam) yang mutlak benar dan berasal dari Tuhan. Sementara itu, kebudayaan yang merupakan inovasi kreatif manusia yang relatif terus berubah dan berkembang. Kebudayaan sebagai lahw wa la'ib (permainan sia-sia) atau alah al-malahi (pemuas nafsu dan nikmat), bidah yang dilarang, haram dan harus dijauhi. Sikap diatas didasari hadits yang disabdakan Nabi dalam khutbahnya:

“Sesungguhnya sebaik-baik perbincangan adalah Al-Qur'an, sebaik-baik petunjuk adalah petunjuk Muhammad, dan upaya membuat-buat sesuatu yang baru adalah perkara yang buruk, dan upaya itu adalah bidah, dan setiap bidah itu adalah sesat, dan setiap kesesatan itu membawa ke neraka."

Karena tak mudah hidup tanpa budaya, inovasi yang baik disebut bid'ah hasanah walaupun batas hasanah dan dhalalah amat tipis dan bertumpang tindih. Sementara kesalehan dilukiskan sulit dan bertumpang tindih. Islam adalah sebuah agama hukum (religion of law). Hukum agama diturunkan oleh Allah Swt., melalui wahyu yang disampaikan kepada Nabi Muhammad Saw., untuk dilaksanakan oleh kaum Muslimin tanpa terkecuali, dan tanpa dikurangi sedikitpun. Dengan demikian, watak dasar Islam adalah pandangan yang serba normatif dan orientasinya yang serba legal formalistic. Islam haruslah diterima secara utuh, dalam artian seluruh hukum-hukumnya dilaksanakan dalam kehidupan bermasyarakat pada semua tingkatan. (Wahid, 2001, p. 101)

\section{E. AL-QUR'AN MENJABARKAN KONSEP MANUSIA}

Dalam Al-Qur'an, ada tiga kata yang sering digunakan untuk menunjukkan arti kata manusia, yaitu insan, basyar, dan Bani Adam. Kata insan dalam Al-Qur'an dipakai untuk manusia yang tunggal sedangkan jamaknya dipakai kata an-nas, unasi, insiyya, anasi. Adapun kata basyar dipakai untuk tunggal dan jamak. Pemakaian kata insan ketika berbicara mengenai manusia menunjuk suatu pengertian adanya kaitan dengan sikap, yang lahir dari adanya kesadaran penalaran. (Asy’arie, 1992, p. 22) Kata insan juga digunakan Al-Qur'an untuk merujuk kepada manusia dengan seluruh totalitasnya, 
baik jiwa maupun raga. Manusia berbeda antara seseorang dengan yang lain adalah akibat perbedaan fisik, mental, dan kecerdasan. (Shihab, 1996, p. 280)

Kata insan jika dilihat dari asal katanya nasiya yang artinya lupa, menunjuk adanya kaitan dengan kesadaran diri. Untuk itu, apabila manusia lupa terhadap suatu hal, disebabkan karena kehilangan kesadaran terhadap hal tersebut. Maka dalam kehidupan agama, jika seseorang lupa sesuatu kewajiban yang seharusnya dilakukannya, mak ia tidak berdosa, karena ia kehilangan kesadaran terhadap kewajiban itu. Tetapi hal ini berbeda dengan seseorang yang dengan sengaja lupa terhadap sesuatu kewajiban. Sedangkan kata insan untuk penyebutan manusia yang terambil dari akar al-uns atau anisa yang berarti jinak dan harmonis, karena manusia pada dasarnya dapat menyesuaikan diri dengan realitas hidup dan lingkungannya. Manusia mempunyai kemampuan adaptasi yang cukup tinggi, untuk dapat menyesuaikan diri dengan perubahan sosial maupun alamiah. Manusia menghargai tata aturan etik, sopan-santun, dan sebagai makhluk yang berbudaya, ia tidak liar baik secara sosial maupun alamiah. (Asy'arie, 1992, p. 20)

Kata basyar dipakai untuk menyebut semua manusia baik laki-laki maupun perempuan, baik satu ataupun banyak. Kata basyar adalah jamak dari kata basyarah yang berarti kulit. Manusia dinamai basyar karena kulitnya tampak jelas, berbeda dengan kulit binatang. Al-Qur'an menggunakan kata ini sebanyak 36 kali dalam bentuk tunggal (mufrad) dan sekali dalam bentuk dual (mutsanna) untuk menunjukkan manusia dari sudut lahiriahnya serta persamaannya dengan manusia seluruhnya. Karena itu Nabi Muhammad Saw. diperintahkan untuk menyampaikan bahwa "Aku adalah manusia (basyar) seperti kamu yang diberi wahyu" (QS. al-Kahfi: 110). Di sisi lain diamati bahwa banyak ayat-ayat Al-Qur'an yang menggunakan kata basyar yang mengisyaratkan bahwa proses kejadian manusia sebagai basyar, melalui tahapantahapan sehingga mencapai tahapan kedewasaan. Firman Allah Swt. (QS. ar-Rum: 20) "Dan diantara tanda-tanda kekuasaan-Nya (Allah) menciptakan kamu dari tanah, ketika kamu menjadi basyar kamu bertebaran”. Bertebaran disini bisa diartikan berkembang biak akibat hubungan seks atau bertebaran mencari rezeki. (Shihab, 1996, p. 279)

Dalam ilmu sosial definisi tentang manusia juga sangat bervariasi, tergantung dari sudut pandang mana manusia dilihat. Jika fokusnya pada kemampuan berpikir, maka pengertian manusia adalah hewan berpikir (animal rasional l hayawan nathiq). Orang yang menitikberatkan pada pembawaan kodrat manusia untuk hidup bermasyarakat, memberi pengertian manusia adalah makhluk sosial (zoom politicon l homo socius). Orang yang menitikberatkan pada adanya usaha manusia untuk mencukupi kebutuhan hidup, memberi pengertian manusia adalah makhluk ekonomi (homo economicus). 
Orang yang menitikberatkan pada keistimewaan manusia menggunakan symbol-simbol (animal symbolicum). Orang yang memandang manusia adalah makhluk yang selalu membuat bentuk-bentuk baru dari bahan-bahan alam untuk mencukupi kebutuhan hidupnya, memberi pengertian manusia adalah makhluk kreatif (homo faber), dan seterusnya. (Mujiono, 2013, p. 361)

Abdurrahman an-Nahlawi, megatakan manusia menurut pandangan Islam meliputi: (1) Manusia sebagai makhluk yang dimuliakan, artinya Islam tidak memposisikan manusiadalam kehinaan, kerendahan atau tidak berharga seperti binatang, benda mati atau makhluk lainnya (QS. al-Isra: 70 dan al-Hajj: 65). (2) Manusia sebagai makhluk istimewa dan terpilih. Salah satu anugerah Allah yang diberikan kepada manusia adalah mapu membedakan kebaikan dan kejahatan atau ketakwaan dan kedurhakaan ke dalam naluri manusia, Allah menanamkan kesiapan dan kehendak untuk melakukan kebaikan dan menghindari keburukan yang akan menjerumuskannya pada kebinasaan. Dengan jelas Allah Swt. menyebutkan bahwa dalam hidupnya, manusia harus berupaya menyucikan diri agar terangkat dalam keutamaan (QS. asy-Syam: 7-10). (3) Manusia sebagai makhluk yang dapat dididik. Allah Swt. telah melengkapi manusia dengan kemapuan untuk belajar, dalam QS. alAlaq: 3dan 5, Allah Swt. telah menganugerahi manusia sarana untuk belajar, seperti penglihatan, pendengaran dan hati. Dengan kelengkapan sarana belajar tersebut, Allah selalu bertanya kepada manusia dalam firman-Nya "afala ta'qilun", "afala tatafakkarun", dan lain-lain pertanyaan Allah kepada manusia yang menunjukkan manusia mempunyai potensi untuk belajar. (An-Nahlawi, 1995, p. 10)

Al-Qur'an menggambarkan manusia sebagai makhluk pilihan Tuhan, sebagai khalifah-Nya di muka bumi, serta sebagai makhluk semi-samawi dan semi-duniawi, yang di dalam dirinya ditanamkan sifat-sifat: mengakui Tuhan, bebas, terpercaya, rasa tanggung jawab terhadap dirinya maupun alam semesta, serta karunia keunggulan atas alam semesta, labgit dan bumi. Keberadaan mereka dimulai dari kelemahan dan ketidakmampuan, yang kemudian bergerak ke arah ketakutan. Tetapi itu tidak akan menghapuskan kegelisahan psikis mereka, kecuali jika mereka dekat dengan Tuhan dan selalu mengingat-Nya. (R. S. Nawawi, Konsep Manusia Menurut Al-Qur'an dalam Nawawi, 2000, p. 11)

\section{F. AYAT AL-QUR'AN DALAM DIRI MANUSIA}

Satu di antara tanda-tanda itu adalah manusia yang bermula dari air mani. Manusia adalah yang terdekat dengan dirinya sendiri. Dan pada diri itulah terdapat halhal yang ajaib yang demikian banyak sebagai salah satu hal yang menunjukkan 
Kebesaran Tuhan. Jika direnungkan semuanya, habislah umur kita sebelum kita mengetahui seperseratus dari jumlah semuanya.

Kebanyakan orang tidak menyadari dirinya sendiri. Bahkan tidak mengenalnya. Bagaimanakah kalian akan mampu mengetahui yang lain? Tuhan sudah menyuruh untuk manusia, "Dan tentang dirimu sendiri, tidakkah kalian pikirkan?" Allah Swt., menyebutkan, bahka manusia dijadikan dari air mani yang menjijikan.

"Celakalah manusia. Kufurlah ia. Dari apakah ia dijadikan?dari air mani, lalu ditakdirkan-Nya, lalu ditunjukkan-Nya jalan kepada-Nya, lalu dimatikan-Nya, dimasukkan ke kubur, kemudian jika dikehendaki dihidupkan-Nya kembali”. (QS. 'Abasa [80]: 17-22)

Di ayat yang lain juga disebutkan:

Sungguh, kami telah menjadikan manusia dari nuthfah tercampur. (QS. AlInsan[76]: 2)

Tuhan menyebutkan juga tentang bagaimana Dia menjadikan nuthfah itu menjadi mudhghah, yang lalu dijadikan sekerat daging, lalu menjadi tulang. Sebutan nuthfah yang berulang-ulang oleh Al-Qur'an itu, bukanlah untuk didengar namanya saja, tanpa dipikirkan apa artinya. Sekarang lihatlah nuthfah itu, setetes air yang menjijikan. Andaikata ini dibiarkan sebentar di udara terbuka, pastilah ia berbuah dan berbau busuk. Bagaimana ia dikeluarkan oleh Tuhan dari antara tulang punggung dan rusuk. Betapa ia menghimpun antara laki-laki dan perempuan, diadakan-Nya cinta di hati mereka. Dengan cinta berahi itu, mereka ditarik-Nya agar menjadi satu. Betapa Dia mengeluarkan nuthfah itu dengan jalan gerak bersetubuh. Betapa Dia mengeluarkan darah haid dari pembuluh-pembuluh urat, lalu dikumpulkannya dalam rahim, dan betapa dia menjadikan bayi itu dari nuthfah, diberinya darah haid, diberinya tumbuh, membesar. Betapa pula Dia jadikan nuthfah yang putih itu berubah darah kental merah, kemudian dibuat-Nya menjadi sekerat daging, dari dari daging itu berubah menjadi tulang, urat saraf, asabat, daging, bahkan berupa anggota lahir lainnya: kepala, mata, telinga, hidung, mulut, dan sebagainya, dan akhirnya tangan dan kaki masing masing lengkap dengan jari dan kuku.

Pikirkanlah keadaannya yang semula dan apa jadinya kemudian. Cobalah untuk merenungkan. Andai kata semua jin dan manusiaitu bersatu dan hendak membuat nuthfah itu hidup, mendengar, melihat, berpikir, berkuasa, berpengetahuan, berjiwa, atau memberinya tulang-tulang, pembuluh darah, urat saraf, urat nadi, atau kulit dan rambut. Tentulah tidak akan mampu. Jika kita renungkansemua rahmat dan kemurahan Allah Swt. serta besarnya kekuasaan dan hikmah dibalik penciptaan itu, pastilah kita silau betapa besar cahaya keajaiban Allah Swt. Sebagai sebuah analogi, anehnya manusia kalau melihat tulisan indah atau sebuah lukisan yang bagus pada tembok umpamanya, ia akan merasa kagum kepada si penulis dan si pelukis, betapa orang itu 
dapat menulis dan melukis sedemikian rupa. Takkan sudah-sudah rasa kagumnya, hati kecilnya akan mengatakan: pandai benar orang itu, sungguh sempurna buatannya, luar biasa kemahirannya. Lalu ia akan melihat kepada keajaiban yang ada pada dirnya sendiri dan pada makhluk-makhluk yang lain. Namun sungguh pun begitu, Pencipta dan Pelukisnya tidak diingatnya. Ia tidak akan merasa kagum atas Kebesaran, Keagungan dan Kebijaksaan-Nya.

Demikianlah serba sedikit hal-hal yang telah menimbulkan keajaiban pada diri kita sendiri. Inilah wilayah yang paling dekat yang bisa ditafakuri. Inilah bukti paling nyata akan Eksistensi Yang Maha Esa. Sayangnya, kebanyakan orang lebih sibuk dengan urutan perut, dan nafsu berahi. Tak ada yang mampu diketahui oleh diri, ketika lapar, makan. Ketika sudah kenyang tidur, kalau sahwat bisa merangsang, bersetubuh. Begitu juga kalau sedang marah, diteruskan dengan berkelahi. Lalu apa bedanya ini dengan binatang? Sebab serupa itulah, binatang.

Sifat manusia yang menghindarkan dari binatang adalah kesadaran atau makrifat wujud Tuhan. Dan, kesadaran ini hanya dapat diperoleh dengan tafakur. Merenungkan kerajaan besar, memikirkan alam malakut yang ada di langit dan bumi, serta aneka keajaiban baik yang ada di dalam maupun yang di luar diri. Hanya dengan makrifat atau kesadaran yang diperoleh dari tafakur, seorang insan dapat sampai ke tingkat golongan malaikatatau dapat digolongkan ke dalam rombongan para nabi. Tingkat ini tidak akan mapu tercapai oleh jenis binatang apa pun. Tidak mungkin mampu dicapai hanya dengan syahwat binatang. Bahkan, manusia jenis ini sebenarnya lebih rendah daripada binatang. Binatang memang sudah takkan mampu sampai ke tingkat itu, tetapi manusia tentu bisa. Hanya ia sendiri saja yang tak berusaha menggunakan tenaga-tenaga batinnya. Ia telah mengingkari nikmat Allah Swt. yang telah diberikan kepadanya. Dengan demikian, mereka itu sama pula dengan binatang, bahkan lebih sesat lagi.

\section{G. AL-QUR'AN DALAM SIKLUS KEHIDUPAN MUSLIM}

Ada beberapa pertanyaan yang selalu menggelayuti hati ketika melihat kondisi kaum muslimin. Pertanyaan itu sebagai berikut:

Bukankah Allah itu Maha Penyayang dan sanagt menyayangi umat beriman? Bukankah Allah itu Maha Berkuasa dan mampu menjayakan kaum muslimin? Bukankah Al-Qur'an yang kit abaca dalam sholat kita adalah sumber kebahagiaan, kejayaan, kemakmuran bagi yang mengamalkannya? Bukankah kaum muslimin itu umat yang terbaik yang diutus untuk memimpin bukan dipimpin umat lain, mendidik bukan dididik umat lain? Bukan umat Islam dijadikan Allah sebagai umat yang satu?

Kemudian, apabila ingin diproyeksikan hakekat di atas dengan kondisi kaum muslimin pada masa ini, maka hasilnya maka akan menutut kita untuk lebih merenung, dimana kejayaan kaum muslimin?, dimana harga diri kaum muslimin?, bahkan dimana 
harga darah seorang muslim di mata kaum muslimin sendiri?, dimana kepemimpinan, kejayaan kaum muslimin di atas kaum yang lainnya?, dimana solidaritas sesama kaum muslimin? Dalam skala nasional maupun internasional.

Allah Swt. kemudian menyindir melalui firman-Nya:

"Belumkah datang waktunya bagi orang-orang yang beriman, untuk tunduk hati mereka mengingat Allah dan kepada kebenaran yang telah turun (kepada mereka), dan janganlah mereka seperti orang-orang yang sebelumnya telah diturunkan Al kitab kepadanya, kemudian berlalulah masa yang panjang atas mereka lalu hati mereka menjadi keras. dan kebanyakan di antara mereka adalah orang-orang yang fasik". (QS. al-Hadid [57]: 16)

Dan Rasulullah Saw. melalui rintihannya kepada Sang Penguasa alam lahir dan batin yang diabadikan juga di dalam Al-Qur'an: "Berkatalah Rasul: "Ya Tuhanku, Sesungguhnya kaumku menjadikan Al Quran itu sesuatu yang tidak diacuhkan".

Persepsi masyarakat pada umumnya mengenai kepribadian Muslim memang berbeda-beda. Bahkan diantara banyaknya masyarakat, ternyata tidak banyak yang mempunyai pemahaman minor (baca: sempit) sehingga menilai pribadi Muslim seolah hanya tergambarkan pada diri orang yang hanya tertib dalam menjalankan pengamalan Islam dari aspek ibadah saja, pada sebenarnya itu hanyalah salah satu sudut pandang dan masih banyak sudut lain yang harus melekat pada kepribadian seorang Muslim. Oleh karena itu, standar pribadi Muslim yang berdasarkan Al-Qur'an dan Sunnah merupakan sesuatu yang harus dirumuskan, sehingga dapat menjadi indikator bagi pembentukan pribadi Muslim yang sempurna sesuai dengan Al-Qur'an.

Di sudut yang lain, agama Islam memandang manusia terdiri dari dua unsur, yakni unsur (ardhi: bumi) dan (samawi: langit). Unsur bumi (rendah) adalah jasmaniah dan unsur samawi (tinggi) adalah ruhaniah. Jasmani memiliki dorongan dan hawa nafsu, jika tidak diarahkan ia dapat membuat kesalahan atau penyimpangan, meskipun selalu mengajak manusia ke jalan yang lurus dan kepada perbuatan yang benar, namun karena pengaruh dari faktor luar ataupun dalam dari dirinya, ia dapat tergelincir dan melaksanakan perbuatan yang melanggar ketentuan, sehingga ia memerlukan suatu kompas untuk mengarahkannya kembali ke arah yang benar yaitu Al-Qur'an. Penerapan nilai-nilai yang agung nan luhur agama yang bersumber dari Al-Qur'an dalam siklus kehidupan Muslimin merupakan suatu keniscayaan, khusunya di era globalisasi saat ini. terlebih lagi, dunia kini terasa sebuah ornament kecil yang mampu digenggam oleh setiap tangan. Interkasi antar negara, peradaban dan budaya semakin mudah dilakukan. Proses saling mempengaruhi antar satu budaya dengan budaya yang lain semakin intens dan dengan proses yang gradual, baik budaya itu bersifat positif atau pun negatif. Proses saling mempengaruhi tersebut pada akhirnya menjadikan sebuah peradaban, budaya dan agama tercampuri dengan unsur-unsur yang lain. Hal ini menimbulkan suatu bentuk benturan bagi ideologi dan budaya lain yang tidak sesuai dengan karakteristik sosial 
kulturnya. Oleh karenanya, siklus kehidupan kaum Muslimin harus mampu sesuai dengan nilai-nilai agung yang terdapat dalam Al-Qur'an.

Sesesorang yang Islam disebut dengan Muslim. Muslim adalah orang atau seseorang yang menyerahkan dirinya secara sungguh-sungguh kepada Allah. Jadi, dapat dijelaskan bahwa "wujud pribadi Muslim" itu adalah manusia yang mengabdikan dirinya kepada Allah, tunduk dan patuh serta ikhlas dalam amal perbuatannya, karena iman kepada-Nya. Pola seseorang yang beriman kepada Allah, selain berbuat kebajikan yang diperintahkan oleh Allah di dalam Al-Qur'an adalah membentuk kesinambungan dan keseimbangan antara pondasi Islam, Iman dan Ihsan. Seseorang yang dapat dengan benar melaksanakan aktivitas hidupnya seperti mendirikan shalat, menunaikan zakat, menepati janjinya apabila ia berjanji, dan sabar dalam kesempitan penderitaan serta peperangan, maka mereka disebut sebagai Muslim yang taqwa dan dinyatakan sebagai insan yang shidiq (benar).

Secara terminologis kepribadian Islam memiliki arti serangkaian perilaku normatif manusia, baik sebagai makhluk individu maupun makhluk sosial yang normanya diturunkan dari ajaran Islam dan bersumber dari Al-Qur'an dan Hadits. (Mujib, 2006, p. 82) Kepribadian Muslim dalam kontek ini barangkali dapat diartikan sebagai identitas yang dimiliki seseorang sebagai cirri khas bagi keseluruhan tindaktunduk (perilaku) sebagai Muslim, baik yang disampaikan dalam tingkah laku secara lahiriah maupun sikap batinnya. Tingkah laku lahiriah dapat dicontohkan seperti, berkata-kata berjalan, tidur, makan, minum, berhadapan dengan guru, orang tua, kerabat, teman sejawat, dan sebagainya. Sedangkan sikap batin seperti, bersyukur, bersabar, ikhlas, dan sikap terpuji lainnya yang timbul dari kebaikan tubuh batin.

Kemudian ciri khas dari tingkah laku tersebut dapat dipertahankan sebagai kebiasaan yang tidak dapat dipengaruhi sikap dan tingkah laku orang lain yang bertentangan dengan sikap yang dimiliki. Ciri khas tersebut hanya mungkin dapat dipertahankan jika sudah terbentuk sebagai kebiasaan dalam waktu yang lama. Selain itu sebagai individu setiap muslim memiliki latar belakang pembawaan yang berbedabeda. Perbedaan individu ini diharapkan tidak akan mempengaruhi perbedaan yang akan menjadi kendala dalam pembentukan kebiasaan ciri khas secara umum. (Khulaisie, 2016, p. 42)

Kehidupan seorang Muslim haruslah sesuai dengan aturan-aturan yang ditetapkan Al-Qur'an. Dalam mengarungi proses kehidupan dimulai dari kelahiran hingga sampai maut menjemputnya untuk menuju kehidupan yang hakiki nan sempurna. Al-Qur'an menegaskan bahwa contoh ideal insan Qur'ani bagi seorang Muslim adalah Nabi Muhammad Saw., yang mana kebanyakan sarjana Muslim menyebut bahwa baginda Muhammad Saw., meruapakan manusia sempurna atau manusia universal, yang 
diistilahkan oleh Syaikhul Akbar Muhyidin Ibnu Arabi sebagai Insan Kamil. Allah Swt., ber-Firman:

Sesungguhnya telah ada pada (diri) Rasulullah itu suri teladan yang baik bagimu (yaitu) bagi orang yang mengharap (rahmat) Allah dan (kedatangan) hari kiamat dan Dia banyak menyebut Allah. (QS. Al-Ahzab [33]: 21)

Kemudian, di dalam sebuah hadits populer juga disebutkan bahwa Rasulullah Saw., diadakan demi memanipurnakan kesejatian perilaku seorang Muslim bahkan manusia yang sejalan dengan Al-Qur'an:

"Dari Abu Hurarirah r.a: Sesungguhnya Rasulullah Saw. telah bersabda: Sesungguhnya aku (Rasulullah) telah diutus untuk menyempurnakan akhlak yang baik. (H.R. Al-Hakim no. 4820)

Jika kehidupan seorang Muslim selaras dengan Al-Qur'an dan hadits, maka ia dianggap sebagai seorang Muslim yang baik. Jika sebaliknya, maka ia mendapatkan predikat sebagai seorang Muslim yang buruk. Apabila nilai-nilai Al-Qur'an sudah hilang dari diri manusia, maka akan terwujud keruntuhan suatu tatanan masyarakat yang dimulai dari fitrah, dimulai dari kebaikan menuju kerusakan yang memilukan.

Di antara ciri-ciri dari perilaku Qur'ani dalam kehidupan seorang Muslim adalah sebagai berikut:

\section{Berilmu}

Memang tidak bisa dipungkiri bahwa bahwa ilmu adalah pondasi, pemimpin serta korektor segala aktivitas atau pengalaman. Dalam menjalani titah kehidupannya seorang Muslim sangat memerlukan ilmu, tentunya adalah ilmu yang berkaitan dengan, akidah, memperbaiki ibadah dan istiqomah dalam mu'amalah.

Bagaimanapun ilmu harus dimiliki terlebih dahulu, sebab ibadah menjadi percuma tanpa ilmu. Ilmu ada poros. Segala sesuatu berputar mengelilinginya. Ilmu dan ibadah adalah dua permata. Demi ilmu dan ibadah itulah, disusun segala apa yang kamu lihat dan dengar tentang kitab-kitab karya para ulama, ajaran guru-guru, nasihat para penasihat, dan pikiran para pemikir. Untuk ilmu dan ibadah juga kitab-kitab suci itu diturunkan Allah Swt. Semua rasul diutus hanya untuk ilmu dan ibadah. Bahkan, langit dan bumi diciptakan oleh Allah Swt. hanya untuk ilmu dan ibadah. Begitu pula semua makhluk yang ada di langit dan bumi, baik yang hidup dan yang tak hidup. Sekarang renungkanlah dua ayat dalam kitab Allah (Al-Qur'an), salah satunya ialah:

"Allah yang menciptakan tujuh langit dan dari (penciptaan) bumi juga serupa. Perintah Allah berlaku padanya, agar kamu mengetahui bahwa Allah Maha Kuasa atas segala sesuatu, dan ilmu Allah benar-benar meliputi segala sesuatu”. (QS. AlThalaq: 12)

Dengan tafakur tentang langit dan bumi, kita berharap memperoleh ilmu. Sepenggal ayat di atas sudah cukup dijadikan dalil untuk mengetahui bahwa ilmu itu 
mulia. Terutama ilmu Tauhid. Dengan ilmu ini, kita mengenal Allah Swt. beserta AsmaNya, Sifat-Nya, Perbuatan-Nya dan sebagainya. Ilmu adalah permata yang lebih mulia dari ibadah. Oleh karena itu Nabi Muhammad Saw. bersabda yang artinya:

"Kelebihan orang berilmu atas orang yang ibadah seperti kelebihanku atas orang yang terendah dari umatku". (H.R. Tirmidzi) ${ }^{1}$

Dengan ini jelaslah bahwa ilmu itu adalah permata yang lebih mulia daripada ibadah. Namun, setiap hamba pun tidak boleh tidak harus beribadah disertai ilmu. Jika tidak, ilmunya akan menjadi debu yang berhamburan ditiup oleh angin. Ilmu itu diibaratkan bagaikan pohon, sementara ibadah adalah salah satu dari buahnya, yang menjadikan pohon itu lebih mulia. Memang pohon adalah pokoknya, tetapi manfaatnya terletak pada buahnya.

Namun, menjadi sebuah pemandangan yang distorsi di masyarakat, ilmu dibedakan menjadi ilmu agama dan ilmu umum. Pemahaman ini kemudian lebih dikuatkan dengan adanya pembagian sekolah yang disebut dengan sekolah umum dan sekolah agama atau yang lebih dikenal dengan madrasah. Sesungguhnya para 'ulama tidak membagi ilmu dengan pembagian yang demikian. Bila membaca berbagai literatur akan didapati bahwa yang dibedakan oleh para 'ulama bukanlah jenis ilmunya, namun hukum dalam memperlajarinya. Di dalam kitab ihya Ulumiddin misalnya, Imam alGhazali membedakan ilmu menjadi ilmu yang fardlu 'ain hukumnya untuk dipelelajari dan ilmu yang fardlu kifayah hukumnya untuk dipelajari.

Ilmu yang fardlu kifayah hukum mempelajarinya berarti tidak setiap orang Islam wajib mempelajari ilmu tersebut. Bila ada satu di antara mereka yang telah mempelajarinya, maka sudah cukup menggugurkan orang Islam (muslim) yang lain untuk mempelajarinya. Termasuk dalam kategori ilmu ini adalah ilmu hadits, ilmu tafsir, ilmu kedokteran, ilmu biologi, dan lain sebagainya. Bila ada satu orang Islam yang mempelajarinya maka gugurlah kewajiban orang Islam lainnya untuk mempelajarinya.

Sedangkan ilmu yang hukum mempelajarinya adalah fardlu ain maka, ilmu ini tidak bisa tidak harus dipelajari dan dipahami oleh setiap individu Muslim. Tak ada celah bagi seorang Muslim untuk tidak mempelajari ilmu dalam kategori ini. Lalu ilmu apa saja yang hukum mempelajarinya termasuk dalam kategori fardlu ain ? Menurut Syaikh Zainudin al-Malibari, bahwa ada 3 (tiga) ilmu yang wajib dipelajari oleh setiap orang Muslim dengan kewajiban fardlu ain. Ketiga ilmu itu adalah ilmu yang

1 Hadits ini sanadnya adalah Hasan. Juga diperkuat oleh riwayat yang lainnya. Diriwatkan oleh Al-Harits bin Abi Huzamah dari Abi Said Al-Khudri, diperkuat oleh riwatar Turmudzi dari Abi Umamah. 
menjadikan ibadah menjadi sah, ilmu yang mengesahkan aqidah, dan ilmu yang menjadikan hati menjadi bersih. Syaikh Zainudin menuturkan:

"Pelajarilah ilmu yang mengesahkan ketaatan, mengesahkan aqidah serta mensucikan hati. Ketiganya ini fardlu ain hukumnya, ketahuilah, amalkanlah, maka terwujud keselamatan dan kehormatan". ${ }^{2}$

Inilah tiga ilmu yang setiap orang Islam wajib mempelajarinya: Pertama, Ilmu yang menjadikan sahnya ibadah kepada Allah adalah ilmu fiqih yang membahas tentang bagaimana semestinya seorang Muslim beribadah kepada Allah Swt. Sebagai contoh, setiap Muslim wajib mempelajari ilmu tentang bagaimana caranya shalat yang benar dan baik. juga ia wajib mempelajari berbagai ilmu yang berkaitan dengan keabsahan berwudlu, mensucikan macam-macam najis, bertayamum, beristinja dan lain sebagainya. Kedua, ilmu yang menjadikan aqidah atau kepercayaan seseorang menjadi benar sesuai dengan aqidah yang dianut oleh ulama Ahlussunah wal jama'ah. Dengan mempelajari dan memahami ilmu ini, maka seseorang akan terjaga dari aqidah-aqidah yang rusak dan tidak benar seperti aqidah Mu'tazilah, Jabariyah, dan Mujassimiyah. Orang yang tidak mempelajari ilmu ini maka, dikhawatirkan ia akan salah dalam memahami dan meyakini perihal bagaimana Allah dan permasalahan keimanan lainnya.

Ketiga, ilmu yang menjadikan hati bersih dari berbagai macam akhlak yang tercela seperti, riya', sombong, dengki, hasud, dan berbagai macam penyakit hati lainnya. Ilmu ini wajib pula dipelajari oleh setia orang Muslim mengingat perilaku orang tidak hanya apa yang dilakukan oleh anggota badan secara lahir, namun juga perilaku-perilaku dan gerak-gerik batin.

Sayyid Bakri Al-Makki, memberikan penjelasan masalah ini di dalam karya kitabnya Kifayatul Atqiya' Minhajul Ashfiya'. Beliau menuturkan bahwa tak ada kelonggaran bagi seorang pun untuk tidak mengetahui ilmu tersebut. Inilah ilmu syariat yang bermanfaat. Tak cukup dengan mempelajari dan mengetahuinya saja. Orang yang telah mempelajarinya juga mesti mengamalkannya. Karena siapapun yang telah mengetahui ketiga ilmu ini tidak akan bisa selamat kecuali dengan mengamalkannya.

Sebab, untuk mendapatkan keselamatan di akhirat kelak serta tingginya derajat di dunia dan akhirat tidak bisa lepas dari tiga hal: keyakinan atau aqidah yang benar, ibadah yang benar, dan hati yang bersih. Hal ini semestinya menjadi perhatian bagi setiap orang Muslim. Lebih-lebih menjadi perhatian bagi para orang tua untuk lebih mengutamakan ketiga ilmu tersebut bagi para generasi penerusnya. Apabila sampai dengan akil baligh seorang anak belum tahu bagaimana semsetinya beraqidah dan beribadah kepada Allah sehingga ia melakukan kesalahan, maka orang tua akan ikut

2 Syaikh Zainudin al-Malibari, Mandhumatu Hidayatil Adzika' ila Thariqil Auliya', disyarah oleh Sayid Bakri al-Makki dalam Kifayatul Atqiya' wa Minhajul Awliya'. 
menanggung akibat dari kesalahan tersebut. Karena keteledorannya yang tak memberikan ilmu agama yang cukup saat anak masih dalam keadaan belum baligh.

\section{Ikhlas}

Allah Swt. berfirman:

Artinya: "Ingatlah, bagi Allah agama yang murni." (QS. Az-Zumar [39]: 3).

Sedangkan di sebuah hadits dari Anas bin Malik diceritakan bahwa Rasulullah Saw. bersabda:

Artinya: "Tiga perkara yang tidak bisa dikhianati hati seorang Muslim, yaitu: keikhlasan amal karena Allah Swt., saling menasihati dalam penguasaan masalah, dan tetapnya jamaah umat Islam.” (H.R. Abu Bakrah) ${ }^{3}$

Menurut Imam al-Qusyairi, "ikhlas adalah penunggalan Al-Haqq dalam mengarahkan semua orientasi ketaatan. Dia dengan ketaatannya dimaksudkan untuk mendekatkan diri pada Allah semata, tanpa yang lain, tanpa dibuat-buat, tanpa ditujukan untuk makhluk, tidak untuk mencari pujian manusia atau makna-makna lain selain pendekatan diri pada Allah”. Bisa juga diartikan bahwa ikhlas merupakan penjernihan perbuatan dan campuran semua makhluk atau pemeliharaan sikap bagi pengaruhpengaruh pribadi. (Naisaburi, 2007, pp. 296-297)

Rasulullah Saw., pernah ditanya tentang makna ikhlas, lalu dijawab: "Saya bertanya Jibril a.s. tentang ikhlas, apa itu ? Dan, Tuhan pun menjawab: Yaitu, rahasia dari rahasia-Ku yang Aku titipkan pada hati orang yang Aku cibtai di antara hambahamba-Ku". ${ }^{4}$ Sementara Dzun Nun Al-Mishri berkata, "Ikhlas tidak akan sempurna kecuali dengan kebenaran dan sabar di dalam ikhlas. Shidiq tidak akan sempurna kecuali dengan ikhlas dan terus-menerus di dalam ikhlas”. Abu Ta'qub As-Susi berkata, "Kapan saja seseorang masih memandang ikhlas dalam keikhlasannya, maka keikhlasannya membutuhkan keikhlasan. ${ }^{5}$

Sementara, Imam al-Ghazali di dalam kitabnya ihya' ulumuddin, menjelaskan tentang keutamaan dan pentingnya keikhlasan dengan mengutip firman Allah Swt.:

"Padahal mereka tidak disuruh kecuali supaya menyembah Allah dengan memurnikan ketaatan kepada-Nya dalam (menjalankan) agama yang lurus, dan supaya mereka mendirikan shalat dan menunaikan zakat; dan yang demikian Itulah agama yang lurus.” (QS. al-Bayyinah [98]: 5)

3 Hadits riwayat Abu Bakrah dan dikeluarkan Imam Ahmad dalam Musnadnya 5/183. AlHasyimi menyebutkannya dalam Majma'uz Zawaid 1/137-139. Ibnu Hibban dan Ibnu Hajar menshahihkannya. Hadits ini riwiyatkann oleh sahabat.

4 Hadits dikeluarkan oleh Al-Qazwaini dalam Musalsalat-nya dari Khuzaifah

5 Hakikat orang ikhlas adalah tidak melihat keikhlasannya dan tidak diam terhadapnya. Kapan saja menentang demikian, maka keikhlasannya tidaklah sempurna, bahkan sebagian pendapat menyebutnya riya. Mereka berkata, "Riyanya ahli ma'rifat lebih utama ketimbang ikhlasnya para murid". 
Dan juga di dalam QS. al-Nisa' [4]: 146:

"Dan Sesungguhnya pada binatang ternak itu benar-benar terdapat pelajaran bagi kamu. Kami memberimu minum dari pada apa yang berada dalam perutnya (berupa) susu yang bersih antara tahi dan darah, yang mudah ditelan bagi orangorang yang meminumnya."

Berdasarkan ayat diatas, al-Ghazali menjelaskan bahwa susu yang bersih, ialah susu yang tidak bercampur dengan darah, najis yang berada di dalam perut binatang, dan bahan-bahan yang lain. Antonim daripada ikhlas adalah ishrak (penyekutuan), maka apabila seorang Muslim tidak menjadi pribadi yang mukhlis, maka ia dikenali sebagai musyrik. (Hamat, n.d., pp. 44-45)

Perhatian dan kekaguman seorang Muslim atas amal-amalnya. Hal ini juga menyebabkan dia terhalang dari Zat yang karena-Nya dia beramal dan kepada-Nya dia beribadah yaitu Allah Swt. Adapun yang menghindarkan seorang Muslim dari perhatiannya terhadap amalnya adalah pengetahuannya tentang rahmat dan karunia Allah terhadapnya, dan kesadarannya bahwa dia dan amalnya diciptakan oleh Allah semata. Allah berfirman didalam Al-Qur'an QS. Ash-Shaffat [37:] 96, yang artinya: "Allah menciptakan kalian dan apa yang kalian perbuat." (Al-Qur'an dan Terjemahnya (Al-Hikmah), 1983, p. 449)

Seorang Muslim harus mampu berusaha untuk mencari kesadaran bahwa dirinya sebenarnya hanyalah manifestasi dari perbuatan Allah Swt. Jika seorang penempuh jalan ketuhanan memperhatikan sifat hawa nafsunya dengan seksama, maka dia akan mengetahui bahwa sifatnya adalah sebagaimana dalam firman-Nya:

"Dan aku tidak (menyatakan) diriku bebas (dari kesalahan), karena sesungguhnya nafsu itu selalu menyuruh kepada kejahatan, kecuali (nafsu) yang Diberi rahmat oleh Tuhan-ku. Sesungguhnya Tuhan-ku Maha Pengampun, Maha Penyayang". (QS. Yusuf [12]: 53) (Al-Qur'an dan Terjemahnya (Al-Hikmah), 1983, p. 242)

Dengan begitu dia akan mengetahui bahwa segala bentuk kebaikan yang bersumber darinya semata-mata adalah Karunia dan Rahmat dari Tuhannya. Dan seketika itu dia juga mulai meresapi akan firman Tuhannya:

"Wahai orang-orang yang telah beriman, janganlah kamu mengikuti langkahlangkah setan. Barangsiapa yang mengikuti langkah-langkah setan, maka sesungguhnya setan itu menyuruh mengerjakan perbuatan yang keji dan munkar. Sekiranya tidak karena karunia Allah dan Rahmat-Nya kepada kalian, niscaya tiada seorang pun dari kalian bersih dari perbuatan-perbuatan keji dan munkar selama-lamanya ." (QS. An-Nur [24]: 21) (Al-Qur'an dan Terjemahnya (AlHikmah), 1983, p. 352)

Oleh karena itu, solusi agar seorang Muslim sejati dapat terhindar dari perhatian dan kekagumannya terhadap amalnya adalah dengan mengetahui kondisi jiwanya dan apa-apa yang ada didalamnya. Oleh karena itu dia harus berjuang untuk memperoleh pengetahuan tersebut. 


\section{Jujur}

Perilaku manusia sifatnya relatif, bisa kuat, dan bisa berubah menjadi lemah bahkan perilaku seseorang bisa menjadi jahat, tidak beda dengan iman seseorang yang dalam siklusnya mengalami naik-turun bahkan menghilang. Kejujuran cermin dari ketaqwaan seorang hamba yang beriman, sesuai dengan Firman Allah Swt.: "Hai orang-orang yang beriman, bertaqwalah kepada Allah, dan hendaklah kamu bersama orang-orang yang benar". Jujur adalah berserasinya antara hati, ucapan dan perbuatan, dan pastilah tidak rela dikatakan bohong atau disamakan dengan perilaku hewan yang tidak memiliki akl dan pikiran. Jujur mencerminkan sikap hati yang menggambarkan ketaatan seseorang kepada Allah dan Rasul-Nya. (Hatta, 2010, p. 119) Seorang Muslim yang jujur pasti tetap patuh pada Allah dan menjalankan tuntutan Rasulullah Saw. Perilaku jujur mencerminkan keimanan, etika, dan moral seseorang, dia mengakui Sang Pencipta dan yakin akan pembalasan atas perbuatan baik dan neraka terhadap perilaku munkar. Dasar pemikiran terhadap pengakuan dan keyakinan terhadap Sang Pencipta, menjadi pondasi membudayakan kejujuran terhadap sistem kehidupan masyarakat. Pemikiran tersebut menjadi kekuatan batin seorang untuk melahirkan perilaku yang penuh tanggungjawab, sesuai dengan sabda Rasulullah Saw., "Jauhi dusta, karena dusta akan membawa kepada dosa dan dosa membawamu ke neraka. Langgengkanlah berkata jujur karena, akan membawamu kepada perilaku kebajikan dan membawamu ke surga". (Asmara, 2002, p. 81)

Menurut Imam al-Ghazali, ada 6 (enam) tingkatan kejujuran. Orang yang mencapai derajat kejujuran yang sempurna layak disebut sebagai orang yang benarbenar jujur, diantaranya adalah sebagai berikut: Pertama, jujur dalam perkataan, di setiap situasi, baik yang berkaitan dengan masa lalu, masa sekarang dan yang akan datang. Kedua, kejujuran dalam niat, hanya karena Allah Swt., menafikan tendesi yang lainnya. Ketiga, kejujuran dalam bertekad. Seseorang bisa saja mempunyai tekad yang bulat untuk bersedekah bila dikarunia rezeki. Juga bertekad untuk berbuat adil bila dikaruniai kekuasaan. Namun adakalanya tekad itu disertai dengan kebimbangan, tetapi juga merupakan kemauan bulat yang tapa disertai rasa ragu. Orang yang mempunyai tekad yang bulat lagi kuat disebut sebagai orang yang benar-benar kuat dan jujur. Keempat, memenuhi tekad. Seringkali jiwa dibanjiri dengan kemauan yang kuat pada mulanya, tetapi ketika menginjak tahap pelaksanaan, bisa melemah. Karena janji tekad yang bulat itu mudah, namun menjadi berat ketika dalam pelaksanaan. Kelima, kejujuran dalam beramal. Tidak mengekspresikan hal-hal batin, kecuali batin itu sendiri memang demikian adanya. Artinya, perlu adanya keselarasan dan keseimbangan antara yang lahir dan batin. Keenam, kejujuran dalam maqam-maqam (kedudukan/tingkatan) 
agama. ini adalah peringkat kejujuran tertinggi. Seperti maqam takut (khauf), harapan (raja'), cinta (hub), ridha, tawakal, dan lain-lain. (Muhasim, 2017, p. 185)

Imam al-Ghazali berusaha memberikan pemahaman kepada kaum Muslimin bahwa, membangun perilaku jujur memerlukan usaha yang sungguh-sungguh. Yang muncul dari jiwa dan hati yang penuh dengan dengan kesadaran. Pikiran dan akal yang sehat nan bersih, sehingga motivasi kejujuran yang timbul pada akhirnya mampu untuk diwujudkan dalam action (perilaku/amal) yang nyata. Hingga dengannya (amal) karena dibangun diatas pondasi kejujuran yang bagus dan baik, sehingga menghantarkan pelakunya kepada tingkat beragama yang tinggi di atas manusia pada umumnya yang belum tentu mencapai tingkatan yang demikian. Dikarenakan anugerah yang diberikan oleh Allah Swt. diantara para hamba-hamba-Nya antara satu dengan yang lainnya berbeda, bergantung sejauhmana persiapan hamba menata niat dan motivasi dalam dirinya.

\section{H. SIMPULAN}

Islam bukanlah lahir dari produk budaya. Akan tetapi, justru membangun sebuah budaya, sebuah peradaban. Peradaban berdasarkan Al-Qur'an dan Sunnah Nabi Saw. tersebut yang pada akhirnya dinamakan dengan perdaban Islam. Dengan kita dapat memulai untuk meletakkan Islam dalam kehidupan keseharaian. Membangun kebudayaan Islam dengan landasan konsep yang berasal dari Islam dengan sumbernya adalah Al-Qur'an.

Kehidupan seorang Muslim haruslah sesuai dengan aturan-aturan yang ditetapkan Al-Qur'an. Muslim harus mampu dan enggan (keinginan) menjunjung tinggi budaya yang menjadi identitas lokal pada dirinya dengan pondasi nilai-nilai suci yang ada dalam Al-Qur'an. Diantaranya adalah sikap ikhlas, ber-ilmu dan jujur menjadi pribadi Muslim dalam menjalani pergulatan waktu yang terus berubah seiring dengan berubahnya pola peradaban manusia. Sehingga, tidak ada alasan bagi seorang Muslim untuk menghilangkan identitas budayanya demi menjadi seorang Muslim yang baik, sebab, Al-Qur'an dan Budaya adalah pakaian yang cocok untuk dikenakan oleh setiap orang Muslim dalam setiap penggalan ritus kehidupan.

\section{DAFTAR PUSTAKA}

Al-Faruqi, I. R. (1998). Atlas Budaya Islam: Menjelajah Khazanah Peradaban Gemilang. Mizan.

Al-Qur'an dan Terjemahnya (Al-Hikmah). (1983). Departemen Agama RI. 
An-Nahlawi, A. (1995). Pendidikan Islam di Rumah, Sekolah dan Masyarakat. Gema Insani Press.

Ash-Shiddieqy, M. H. (1994). Pengantar Ilmu Al-Qur'an /Tafsir. Bulan Bintang.

Asmara, T. (2002). Membudayakan Etos Kerja. Gema Insani.

Asy’arie, M. (1992). Manusia Pembentuk Kebudayaan dalam Al-Qur'an. Lembaga Studi Filsafat Islam.

Gazalba, S. (1989). Masyarakat Islam: Pengantar Sosiologi dan Sosiografi (2nd ed.). Bulan Bintang.

Hamat, Mohd. H. S. Mohd. F. (n.d.). Nilai-Nilai Penting Individu Muslim Menurut alGhazali. Islam Dan Masyarakat Kontemporari.

Hasyim, U. (1982). Apakah Anda Termasuk Golongan Ahlus Sunnah Waljamaah? Bina Ilmu.

Hatta, A. (2010). Tafsir Al-Qur'an Per Kata, Surat At-Taubah. Maghfirah Pustaka.

Khulaisie, R. N. (2016). Hakikat Kepribadian Muslim, Seri Pemahaman Jiwa Terhadap Konsep Insan Kamil. Reflektika, 11(11).

Koentjaraningrat. (1990). Pengantar Ilmu Antropologi (8th ed.). Rineka Cipta.

Koentjaraningrat. (2004). Kebudayaan, Mentalitas dan Pembangunan. Gramedia Pustaka Utama.

Madjid, N. C. (1992). Islam Doktrin dan Peradaban. Paramidana.

Muhaimin. (2005). Kawasan dan Wawasan Studi Islam. Kencana.

Muhasim. (2017). Budaya Kejujuran Dalam Menghadapi Perubahan Zaman. Studi Keislaman Dan Ilmu Pendidikani, 5(1).

Mujib, A. (2006). Kepribadian dalam Psikologi Islam. Raja Grafindo Persada.

Mujiono. (2013). Manusia Berkualitas Menurut Al-Qur'an. Hermeunetik, 7(2).

Naisaburi, A. Q. A. K. H. A. Q. A. (2007). Ar-Risalatul Qusyairiyah fi 'Ilmit Tashawwuf (Risalah Qusyairiyah: Sumber Kajian Ilmu Tasawuf) (U. Faruq, Ed.). Pustakan Amani.

Nawawi, R. S. (2000). Metodologi Psikologi Islam (R. K, Ed.). Pustaka Pelajar. 
Rohmana, J. A. (2014). Memahami Al-Qur'an dengan Kearifan Lokal: Nuansa Budaya Sunda dalam Tafsir Al-Qur'an berbahasa Sunda (No. 1; 3).

Shihab, M. Q. (1996). Wawasan Al-Qur'an. Mizan.

Syaikhu, A. (2010). Al-Qur'an dan Dinamika Kebudayaan. Falasifa, 1(1).

Wahid, A. (2001). Pergulatan Negara, Agama, dan Kebudayaan (2nd ed.). Desantara. Yusuf, A. A. (2002). Wawasan Islam. Pustaka Setia. 